\title{
Chapter 4 Judah Halevi's Fideistic Scepticism against the Backdrop of Developments in the Arabic Culture of His Time
}

From the analysis in the previous chapter, the trends of dogmatic rationalism in Arabic culture have emerged as the most relevant background to the appearance of sceptical manifestations in The Kuzari. Thus, it seems fitting to point to a general historical parallel between the circumstances under which scepticism appeared in Hellenistic antiquity and the circumstances under which sceptical manifestations emerged in Judah Halevi's thought. The Hellenistic sceptical trend formed in reaction to the establishment of the dogmatic rationalist schools, first and foremost the Stoic, Epicurean, and Aristotelian schools of thought in the fourth and third centuries BCE, while the sceptical manifestations in Halevi's thought are a response to and a means of countering the establishment of the dogmatic rationalist schools of Arabic culture, above all the kalām and falsafah schools. For Halevi himself, as a thinker and writer active in the late eleventh and first half of the twelfth centuries, a period when the Arabic variations of Neoplatonism and Aristotelianism were prevalent among Jewish and Muslim writers in al-Andalus, the challenge posed by dogmatic rationalism as processed by the falsafah trends was greater than that posed by the thought of the kalām trends. ${ }^{1}$ In his works, Ibn Sīnā, active in the first decades of the eleventh century, presented a systematic philosophical synthesis that covered all scientific disciplines, including metaphysics, which he called "the divine sciences" (al-ilāhiyāt), which, theologically speaking, is the most significant. Ibn Sīnā's tremendous philosophical achievement made a very profound impression on Arabic rationalists in the following generations. ${ }^{2}$ Ibn Sīnā's thought reverberates throughout The Kuzari more strongly than that of al-Fārābī, falsafah's important representative in the generations preceding Ibn Sinnā's time. ${ }^{3}$ In the specific context of Halevi as an Andalusian thinker, the thought of the contemporaneous Andalusian philosopher Abū Bakr ibn Bāğğah (d. 1139), the first important representative of falsafah in Andalusia, also left a significant imprint on The Kuzari. ${ }^{4}$

In addition to noting the general parallel of circumstances in which classical Hellenistic scepticism appeared and the appearance of scepticism in Halevi's thought, it is also necessary to discuss the specific historical circumstances under

\footnotetext{
1 See the discussion in Krinis, "The Arabic Background of the Kuzari," 17-19.

2 See Dimitri Gutas, "The Heritage of Avicenna: The Golden Age of Arabic Philosophy, 1000-1350," in Avicenna and His Heritage, ed. Jules Janssens and Daniel De Smet (Leuven: Leuven University Press, 2002), 81-97.

3 Krinis, "The Arabic Background of the Kuzari," 4-8.

4 Pines, "Shī'ite Terms and Conceptions," 210-17; Krinis, "The Arabic Background of the Kuzari," 8-11.
}

ว Open Access. (C) 2020 Ehud Krinis, published by De Gruyter. (ख) BY-Nc-ND This work is licensed under the Creative Commons Attribution-NonCommercial-NoDerivatives 4.0 License.

https://doi.org/10.1515/9783110664744-005 
which Halevi formulated his thought as a response to the dogmatic rationalism of his time. As Halevi was operating within the context of Arabic culture, it is necessary to consider the unique circumstances of the development of dogmatic rationalism in Judeo-Arabic thought. Early in the development of dogmatic rationalism in the Muslim-Arabic context, the representatives of Muslim rationalism were confronted by the representatives of Muslim traditionalism. ${ }^{5}$ This confrontation formed an ideological anti-rationalist opposition to rationalist approaches from their very inception. The argument between the traditionalist and rationalist trends continued unabated throughout the classical Islamic period and beyond. ${ }^{6}$ Compared to these circumstances, the conditions of the development of Judeo-Arabic thought are particularly striking, because the emergence and development of dogmatic rationalism in Judeo-Arabic culture was not accompanied by the parallel development of a traditionalist counter-option. All the Jewish thinkers working within Judeo-Arabic thought until Halevi's time - or at least those whose thought is known to us - were of some dogmatic rationalist orientation or another. ${ }^{7}$

This historical fact is important in the construction of Halevi's thought and clarifies Halevi's "splendid isolation" in the social and intellectual setting in which he operated. ${ }^{8}$ Above, in the second chapter, I discussed one well-known ramification of Halevi's intellectual isolation: when he attempted to formulate a polemical response to dogmatic rationalism, he was inclined to explain his position to his colleagues and readers - all of whom were dogmatic rationalists - by using their own terms. In this discussion, I want to focus on another ramification of this situation. In his attempt to articulate a polemical response to dogmatic rationalism, Halevi did not have a convenient traditionalist or other ideological doctrine in the context of Judeo-Arabic thought at his disposal. In the context of Judeo-Arabic thought, Halevi's choice to present an ideological alternative to dogmatic rationalism was there-

5 For the definitions of traditionalism and rationalism in the context of the classical Islamic period, see Abrahamov, Islamic Theology: Traditionalism and Rationalism, ix-xi, 52-53.

6 Abrahamov, Islamic Theology: Traditionalism and Rationalism, chapters 3 and 5; Abramahov, "Scripturalist and Traditionalist Theology," in The Oxford Handbook of Islamic Theology, ed. Sabine Schmidtke (Oxford: Oxford University Press, 2016): 263-80.

7 It seems that the emergence of the counter-rationalist trend in Jewish thought was triggered by the polemics about Maimonides's writings from the end of the twelfth century onwards. In this context, it is interesting to note that one Jewish work of the era which displayed significant similarities with the traditionalist Muslim arguments was Ketav Tamim (Honest Pamphlet) by Moses Taku (fl. first half of the thirteenth century), who lived in central Europe, far from the centres of Islamic culture.

8 Halevi's "splendid isolation" within his circle of friends, fans, and associates was strikingly manifested in their response to his decision to immigrate to the Holy Land. From sections of The Kuzari such as II, 23-24 and V, 22-27, as well as from a few of his poems, we learn that Halevi's decision to travel to the Holy Land was considered incomprehensible by his friends and associates in the higher stratum of Andalusian Jewish society. See Gil and Fleischer, Yehuda Ha-Levi and His Circle, 199-257. 
fore a pioneering endeavour. In doing so, Halevi could not build on precedents in Judeo-Arabic thought. No wonder, therefore, that his main sources of inspiration for formulating this alternative were rooted in non-Jewish Arabic thought. To follow on from the earlier discussion, where I indicated the Hellenistic sources that had been translated into Arabic from which Halevi could have extracted sceptical assertions to use in articulating his own alternative to the dominant dogmatic rationalist thought, I shall at this point address a complementary discussion of trends in Muslim-Arabic thought that are of particular relevance for the articulation of such an alternative.

As noted, the dominance of dogmatic rationalism in various formulations in Judeo-Arabic thought was more evident and obvious than in the parallel MuslimArabic thought. As a Judeo-Arabic thinker, Halevi, who sought to present an ideological alternative to the dominant trend, also made use of components of the traditionalist Muslim approach. In the earlier discussion about the dialogue in I, 11-25, I analysed Halevi's epistemological manoeuvre in this section of the text and his reliance on the traditionalist Muslim epistemological conceptualisation which is centred around the notion of reports ( $a h b \bar{a} r)$ of the past, verifying these reports by relying on direct sense perception ('iyān) and also on concurrent tradition based on multiple chains of transmitters (tawätur). Later on, in the dialogue in I, 43-67, which centres on the veracity of the Jewish chronology ( $\left.t a^{\prime} r i \bar{h}\right)$, he also relies on traditionalist Muslim epistemology. As noted, the section concludes with a reference to the oral tradition (al-naql) being decisive on the matter under discussion. Thus, we may identify an important contribution to The Kuzari from traditionalist Muslim thought when it comes to creating an alternative to the dogmatic rationalist approach. Halevi was not the first Jewish author to utilise traditionalist Muslim terms and patterns in a polemical context, yet he seems to have been the first of them to utilise them in an anti-rationalistic polemical context. ${ }^{9}$ Halevi's use of the terminology and way of thinking that was typical of Muslim traditionalists in these sections allowed him to present a definition of knowledge based on the concept of reporting (habar), which differs in essence from the concept of knowledge in dogmatic rationalism, especially that of falsafah.

In addition to using traditionalist Muslim terminology, which was generally distinct from the terminology of falsafah's dogmatic rationalism, we also see Halevi, in his polemics against his philosophical opponents, arguing with them by using the terminology and way of thinking that was typical of rationalist thought. Two such manoeuvres are notable: first, disputing them using the rationalist approach that is unique to scepticism, which I analysed at length above, a productive way of creating the alternative that Halevi sought to present in The Kuzari. The major contribution here lies in the specific internal logic of sceptical rationalism; namely, in avoid-

9 See the discussion in chapter 3 above. 
ing either the verification or the refutation of certain positions by the use of the "equipollence of counter-arguments" (isostheneia). During the dialogical exchanges in I, 11-25 and I, 66-67, Halevi makes tactical use of this logic as an alternative to the internal logic of dogmatic rationalism, in which assent, verification, and refutation serve as basic components. Second, Halevi disputes the dogmatic rationalism of falsafah by engaging in ad hominem (ilzām) arguments; namely, by tactically adopting his opponents' assumptions only to demonstrate how, further down the line, they fail the test of correlation between these assumptions and the conclusions they derive from them for issues with theological implications. In his ad hominem argumentation, Halevi relies to a considerable extent on al-Ġazālī's precedent in The Incoherence of the Philosophers (Tahāfut al-falāsifah), in which al-Ġazāli used this approach to broadly undermine the core claims of falsafah. ${ }^{10}$ The ad hominem argumentation is essentially negative, making do with undermining one's opponent's stances; it provides nothing on which it is possible to construct an alternative. ${ }^{11}$ Of interest in this regard is Halevi's attempt to append his negative assertions, which he posits against falsafah's notion of emanation (most of which he borrowed from al-Ġazālì), ${ }^{12}$ with his own unique positive non-sceptical theory, which revolves around the notion of "the divine order" (al-amr al-ilāhi) as an alternative to falsafah's concept of emanation. ${ }^{13}$

In terms of presenting an alternative to dogmatic rationalism in general, and that of falsafah in particular, the most significant contribution Halevi found in alĠazālī's thought is related to fideism. Al-Ġazālī articulated this approach with help from the mystical Muslim Șūfì tradition and the terminology associated with it. Although al-Ġazāli was initially a student and then a teacher of dogmatic rationalism in the Ash'arite school of kalām, he rediscovered - or reinvented - himself as a Șūfi mentor at a later stage of his spiritual development. The appearance of fideism in al-Ġazālī's thought is a function of his transition from an early stage of dogmatic rationalism to a later stage of Șūfism. Undergoing a mystical experience and describing it in Șūfî terms provided al-Ǵazālī with an arationalist mystical foundation. In one of his late works, The Deliverance from Error (al-Munqid min al-dalāl), alĠazālī provided a concise and persuasive account of how attaining mystical experiences allowed him to reevaluate the various articulations of dogmatic rationalism in

10 See al-Ġazālīs programmatic exposition regarding his use of this method in The Incoherence of the Philosophers, 9.

11 Ayman Shihadeh, "From al-Ghazālī to al-Rāzī: $6^{\text {th }} / 12^{\text {th }}$ Century Developments in Muslim Philosophical Theology," Arabic Sciences and Philosophy 15 (2005): 147, 164. For the ancient Hellenistic sceptics, who adhered to global scepticism, this kind of negative ad hominem argument was a way of refraining from taking a position oneself. (I owe this observation to Josef Stern.)

12 Harry A. Wolfson, "Hallevi and Maimonides on Design, Chance and Necessity," Proceedings of the American Academy for Jewish Research 11 (1941): 112-17.

13 Davidson, "The Active Intellect in the Cuzari," 393-95. 
both the kalām and the falsafah schools. Relying on mystical experiences, al-Ġazālì identified rationalism's limitations in terms of the knowledge of the divine, which are inherent to rationalism because of its essence; namely, as an approach which privileges human intellectual inquiry even when it comes to divine knowledge. Indepth knowledge of the divine, in the sense of a supra-sensory experience of God's presence and proximity, is possible only by means of the non-intellectual mystical experience of the prophets and Ṣūfì saints. ${ }^{14}$ Halevi was deeply affected by al-Ġazāli's fideist message as primarily spelt out in The Deliverance from Error and how it denied dogmatic rationalism its pre-eminence in defining and attaining knowledge in the realm of belief in the name of the mystical experience and the Șūfi means of cognition characterising it. ${ }^{15}$ As a result, the dialogue between the rabbi and the Khazar king throughout much of The Kuzari's fourth book and in several places in the fifth, such as V, 14, is aimed at the experiential epistemological alternative and the supra-sensory mystical ways of cognition that typify it. In this case, too, the polemical sting of the presentation of an alternative is aimed at dogmatic rationalism, not only that of falsafah, but also that of kalām. ${ }^{16}$

We can therefore discern that at the epistemological level, the traditionalist approach and the mystical Șūfĩ approach as processed by al-Ġazāli served as the two main pillars which supported Halevi's anti-rationalist alternative in The Kuzari. Both of these Muslim traditions were historically important and influential in critiquing the dogmatic rationalist trends in Arabic culture. ${ }^{17}$ It is therefore not surprising that Halevi found these particular Muslim traditions helpful for creating an alternative to dogmatic rationalism in Judeo-Arabic thought.

To conclude this chapter, it behoves us to compare the way that Halevi used the sceptical tradition with the way it was used by other Judeo-Arabic thinkers. At this point of the study, such a comparison can only be made with one thinker, whose connection to scepticism has been substantially studied: Maimonides, the most important thinker to emerge from Judeo-Arabic culture, who was active in the second half of the twelfth century, some decades after Halevi's death. For the sake of this

14 See al-Ghazālī, Deliverance from Error, 57-58 (sec. 15-16), 77-78 (sec. 80-83), 81-88 (sec. 94124), 89 (sec. 141), 97 (sec. 153). See also Eric Ormsby, Ghazali: The Revival of Islam (Oxford: Oneworld, 2007), 104-5.

15 Lobel, Between Mysticism and Philosophy, 171-76.

16 See, for instance, the description of Abraham in IV, 17 and the explanation (discussed above) in $\mathrm{V}, 16$ with the example of the inferiority of "people who read treatises on prosody and pay close attention to their poetic meter" compared with "the person who is naturally inclined to it, who 'tastes' the meter of the verses." See also the discussion in Lobel, Between Mysticism and Philosophy, 154-57, 173-74.

17 See, in this context, Abrahamov, Islamic Theology: Traditionalism and Rationalism, 19-27; Heck, Skepticism in Classical Islam, 194-97; Roger Arnaldez, "Ma'rifa," in Encyclopedia of Islam, Second Edition, vol. 6, ed. Clifford Edmund Bosworth, Emeri van Donzelm, and Charles Pellat (Leiden: Brill, 1991): 569-70. 
comparison, I shall start by presenting some background about Maimonides and his philosophical development.

Early in his development, Maimonides's thinking was quite obviously affected by falsafah's dogmatic rationalist approach. He only sought out scepticism at a later stage, when he wrote The Guide of the Perplexed (Dalālat al-hā' 'irīn). ${ }^{18}$ In his earlier years, Maimonides was the great dogmatic Jewish thinker whose first major composition, The Commentary on the Mishnah (Šarh al-mišnah), articulated what became the most influential version of the Jewish catechism: a list of thirteen dogmatic principles of the Jewish faith. ${ }^{19}$ His second great composition, Mishneh Torah (The Code of Maimonides), is constructed according to the format of an apodictic code of law and as such is imbued with an overall dogmatisation that is completely at odds with the open and non-conclusive legal discourse of the Talmud. The early Maimonides of The Commentary on the Mishnah and Mishneh Torah is also the thinker who made the dramatic interpretation, in the spirit of dogmatic rationalism, of identifying falsafah's physics and metaphysics with the Talmudic "work of Creation" (ma'aśeh berešit) and "work of the Chariot" (ma'aśeh merkavah) respectively. ${ }^{20}$ With this highly original and controversial move, Maimonides bestowed the dogmatic seal of approval of the supreme scientific spheres of Aristotelian philosophy on two highly esoteric Jewish traditional themes. So, in Maimonides's case, his achievements as a codifier in The Commentary on the Mishnah and especially in Mishneh Torah, which made him the greatest codifier of Jewish law, went hand in hand with his position as the one who contributed more than any other to the dogmatisation of the Jewish faith. Hence, the possibility that a thinker with a strong predilection for dogmatism like Maimonides could have incorporated sceptical elements into his Guide of the Perplexed later in his life, as suggested by few scholars in the last generation, is both remarkable and fascinating.

Equally remarkable and notable is the fact that almost at the same time, this kind of unexpected development was taking place in the thought of Fahr al-Din alRāzì (d. 1210), a thinker whose centrality to Muslim-Arabic culture is comparable in some ways to Maimonides's place in Jewish literature in terms of reputation and influence. Al-Rāzī's thought is notable for its transition from rigid dogmatic rational-

18 Halbertal, Maimonides: Life and Thought, 302.

19 Moses Maimonides, Šarḥ al-mišnah, ed. and trans. Yosef Kafiḥ (Jerusalem: Mossad ha-Rav Kook, 1963-68), 4:210-17 (Judeo-Arabic original and Hebrew translation); Maimonides, Mishneh Torah, vol. 1, Sefer ha-Madda', Hilekhot Yesodei ha-Torah, ed. Mordechai Dov Rabinowitz, chapters 1-4 (Jerusalem, Mossad ha-Rav Kook, 1993), 3-24.

20 Šarh al-mišnah, 2:377. The impact of Maimonides's catechism has been so profound that a condensed version of it is included in virtually every Jewish daily prayer book (Siddur). For the possible relation between Maimonides's catechism and the Almohad catechism (Maimonides lived under Almohad rule when he began work on his Šarh al-mišnah), see Sarah Stroumsa, "Was Maimonides an Almohad Thinker?” [Hebrew], in Alei Asor, 162-63. 
ism in the spirit of Ash'arite kalām in his early writings to the sceptical pessimism typical of his later works. For al-Rāzì, the transition seems to have been even more radical than the one experienced by Maimonides. ${ }^{21}$ It seems quite certain that Fahr al-Dīn al-Rāzī was a key figure in the development of scepticism in Arabic culture. ${ }^{22}$ Further progress in this field, which might include a comparative study between alRāzì and Maimonides, is likely to advance our understanding of the manifestations of scepticism in this cultural realm.

As already noted above, the possibility that Maimonides embraced a sceptical approach in The Guide of the Perplexed has been most forcibly and thoroughly elaborated and analysed in the studies of Josef Stern. According to Stern, the starting point of scepticism in the Guide of the Perplexed is its emphasis on the basic datum that the human intellect is seated in materiality. This fact is a severe limitation on the intellect's ability to comprehend the purely intellectual beings, the separate intellects, let alone God, a supra-intellectual entity. In other words, the human intellect encounters its most constraining limits in understanding any entity from the metaphysical realms. ${ }^{23}$ The problem is that the aspect of metaphysics that deals with God and the separate intellects is precisely what most intrigues those who are charged with using their intellects and who strive for intellectual perfection; namely, philosophers, those for whom the siren's song of metaphysics is strongest, a temptation they cannot withstand, even if this is also the very field in which their intellects - as is true of all humans, whose minds are mired in the material - are most limited. ${ }^{24}$ Here is where the sceptical approach meets Maimonides. For him, the sceptical approach is a useful tool for making philosophers rein in ther impulse towards dogmatic philosophising in the field of metaphysics. The use of scepticism exposes the fact that the philosophers' pretensions of being able to present clear demonstrative proofs and to reach certain knowledge of metaphysics are lacking a real basis. ${ }^{25}$ Maimonides's transition towards philosophical metaphysics in the Guide of the Perplexed - from the apodictic rationale of dogmatic philosophy to the

21 Shihadeh, The Teleological Ethics of Fakhr al-Dīn al-Rāzī, 181-99; Shihadeh, "From al-Ghazālī to al-Rāzī," 163-77. One should note that Saul Horovitz was the first to point to Fahrr al-Dīn al-Rāzī’s place in the context of the development of scepticism in Arabic literature in his pioneering studies from the beginning of the twentieth century. See Horovitz, "Der Einfluss der griechischen Skepsis," 10-13, 23, 29-30, 43-44, 46.

22 It seems that more than any other writer, it was al-Rāzī and his version of rationalism that provoked the monumental anti-rational response from Ahmad ibn Taymiyyah (d. 1328) and served as a trigger for the inclusion of sceptical components in the thought of this prominent thinker. See, in this context, Shihadeh, The Teleological Ethics of Fakhr al-Dīn al-Rāzī, 198-99; Heck, Skepticism in Classical Islam, 17, 153-92.

23 Stern, The Matter and Form of Maimonides' Guide, 76-77, 80, 124-31, 334, 337.

24 Stern, 81-82, 86-89, 178-79, 186.

25 See, in this context, Sarah Stroumsa, Maimonides in His World: Portrait of a Mediterranean Thinker (Princeton: Princeton University Press, 2009), 44-45, 137-38. 
rationale of sceptical philosophy's non-assent and suspension of judgment - preserved for him the possibility of philosophising about metaphysical matters in light of his growing tendency in his later writings to make a pessimistic epistemological assessment of the human intellect's ability to reach certain knowledge on these matters. $^{26}$

In the discussion of manifestations of scepticism in Halevi's thought earlier in this study, I examined the possibility that the writings of Galen and Ptolemy served as the conduit for selective sceptical stances from Hellenism to Arabic culture in general and The Kuzari in particular. In The Guide of the Perplexed, this is more than a probability, as Maimonides explicitly cites both Galen and Ptolemy in the long discussion devoted to the question of the world's eternity versus its innovation. These citations appear in contexts that are extremely relevant for the argument that Maimonides was forging a selective sceptical approach in his work. Maimonides quotes Galen's sceptical stance on the eternity-versus-innovation question in the context of the aforementioned dismissive appraisal of al-Fārābī's position, an appraisal that Maimonides does not share. ${ }^{27}$ As for Ptolemy's Almagest, Maimonides quotes a section of it in The Guide of the Perplexed II, 24, a chapter of special significance for the forging of his scepticism. While the ideas from the Almagest are taken from the body of the book, they are congruent with the spirit of Ptolemy's abovementioned statement from the book's introduction speaking about his sceptical assessment of the human intellect's cognitive ability in the realm of ungraspable, "unstable and unclear" matters. ${ }^{28}$

If we subsequently compare section V, 14 of The Kuzari with the claims that Maimonides made in The Guide of the Perplexed, we will find that the assertion about the limitations of the human intellect in the realm of metaphysics is made in the context of both authors' mitigated use of scepticism. ${ }^{29}$ However, while Halevi incorporates its use into a fideist framework in whose name he wished to demolish philosophical preoccupation with metaphysics as a legitimate science, Maimonides forgoes the fideist context. In adopting and applying this assertion, Maimonides's intention is not to deny the adherents of philosophy any intellectual investigation

26 Stern, The Matter and Form of Maimonides' Guide, 85-86, 90-96, 184-85, 189-90, 311.

27 Maimonides, Dalālat al-ḥầirīn, II, 15 (203, 1. 29-204, 1.2 = The Guide of the Perplexed, 292).

28 Maimonides, Dalālat al-hă 'irīn, II, 24 (227, 11. 13-17 = The Guide of the Perplexed, 325). Maimonides's reference here can be found in Ptolemy, Almagest, 600.

29 For the characterisation of Maimonides's scepticism as mitigated, see Stern, The Matter and Form of Maimonides' Guide, 5-6, 132, 136-38, 146. Halevi's sceptical attitude, unlike that of Maimonides, expands beyond metaphysics to include fundamental components of Aristotelian physics, such as the doctrine of the four elements of the sub-lunar world (V, 14 [322, 1. 25-324, 1. 24]). Maimonides, on the other hand, more than once asserts the complete credibility of Aristotelian physics regarding the sub-lunar world. See Maimonides, Dalālat al-ḥā'irinn, II, 22 (223, 11. 17-19), II, 24 (228, 11. 15-16 = The Guide of the Perplexed, 319, 326). 
of metaphysics. Rather, he uses the sceptical approach as a methodological tool to guide them in that investigation. In The Guide of the Perplexed, Maimonides presents Aristotle, the father figure of falsafah, as a model of the cautious scholar, taking a selective sceptical approach in all matters pertaining to metaphysics. ${ }^{30}$ The Aristotle of The Guide of the Perplexed, the careful philosopher making sure not to cross the limits of intellectual cognition, is the counterpart to the figure of Socrates that Halevi sketches in The Kuzari. ${ }^{31}$ But the two authors describe this intellectual caution in completely different terms. For Halevi, it is related to the distinction between "human wisdom" and "divine wisdom." Socrates's caution prevents him, as a philosopher, from attempting to go beyond the realm of "human wisdom" and infringing on the realm of "divine wisdom." According to him, the latter is closed to most humans, who are endowed only with their intellect, and only open to those who possess mystical, inspirational cognition. Maimonides's approach, which he projects onto Aristotle, emerges as the approach that is truest to the constant rationalist demand for inquiry - skepsis - in the spirit of the classical sceptical approach. ${ }^{32}$ Maimonides avoids making a clear distinction, as Halevi does, between human and divine wisdom, thus leaving the question of whether intellectual inquiry into metaphysics is appropriate without a clear-cut answer. This non-assent attitude provides further legitimacy of the sceptical kind for the possibility of studying metaphysics; that is, its inquiry as an ongoing exercise. Aristotle's caution in The Guide of the Perplexed is therefore what allows the philosopher to move in the realm of "divine wisdom" and to continue conducting intellectual inquiries in matters pertaining to it.

If we turn to the question of proving the existence of God using the teleological argument in Halevi and Maimonides, we find that both are in proximity to the sceptical approach despite their differing articulations on the subject. In The Guide of the Perplexed I, 72, Maimonides formulates the subject as an antinomy: the two opposing claims - that God is remote and separate from the world and that God is manifest in His providence and governance of every last part of the world - are both backed by demonstrative proofs. ${ }^{33}$ By contrast, for Halevi, in the statement he has the Khazar king speak in I, 20, the three different and antithetical claims on the subject do not have the status of claims that are backed by demonstrative proofs; they are merely questionable assertions. Despite their differences, Maimonides's and Halevi's formulations both bring the issue to the point of the "equipollence of counterarguments" (isostheneia) that is desirable from the sceptical perspective.

30 See Stern, The Matter and Form of Maimonides' Guide, 283-85, 294, 303-4.

31 Danzig, "Socrates in Hellenistic and Medieval Jewish Literature," 156 n. 36.

32 Stern, The Matter and Form of Maimonides' Guide, 242, 246-49, 284-85, 294, 303-4, 312-13.

33 See Maimonides, Dalālat al-hạ̄'irīn, I, 72 (133, 1. 27-134, 1. 3 = The Guide of the Perplexed, 192-93) and the discussion in Stern, The Matter and Form of Maimonides' Guide, 245, 278-79. 
If we now turn to a comparison between Halevi's and Maimonides's positions on the debate over the world's eternity versus its innovation ex nihilo, we see that Maimonides presents a dogmatic conclusion that Halevi avoids. Theoretically, the two thinkers are close to one another in their fundamentally sceptical understanding that in this issue, intellectual inquiry is incapable of deciding between the two contradictory claims. Based on this understanding, in I, 67 of The Kuzari, Halevi reaches the non-dogmatic conclusion that an "adherent of the Law" (al-mutašarri') is not obligated to believe in innovation ex nihilo. An "adherent of the Law" is also allowed to have opinions that do not contradict the belief "that this world came into new existence at a specific time in the past," including the belief that assumes the existence of a prime matter or the opinion that other worlds existed prior to this one. ${ }^{34}$ Compared to Halevi's position here, Maimonides presents a much more rigid stance on the issue: "an adherent of the Law" is bound by a dogmatic obligation to believe in innovation ex nihilo. Consequently, he must reject other positions, even those that are found in the writings of the Talmudic sages about the existence of a prior "order of time" (seder zemanim) to the chronology of our present world. ${ }^{35}$

The approach of rationalist mitigated scepticism thus plays a significant role both in Maimonides's late thought (in the way in which Stern interprets it) and in Halevi's thought (in the way in which it is interpreted here), though for Maimonides - unlike Halevi - its role seems to be more essential. For him, it embodies a rationalistic alternative to dogmatism thanks to which he was able to continue to philosophise about metaphysical issues. Halevi, on the other hand, did not need a sceptical alternative to "save" philosophical metaphysics; from his perspective, seeking to know God and the upper world is not a quest dependent on the capacity of the human intellect, but rather on the capacity of the sensory and mystical perception of humanity's choicest members.

Finally, let me briefly point to what seems to me to be an interesting phenomenon that needs to be studied and clarified. In the course of a period of approximately one hundred years, from around 1100 until around 1200, the two Judeo-Arabic thinkers with lasting influence -Halevi and Maimonides - and the two MuslimArabic thinkers with an equally profound impact - al-Ġazālī and al-Rāzī - became increasingly critical, each in his own unique manner, of their dogmatic rationalistic upbringing. As mentioned above, starting from the ninth century onwards, dogmatic rationalist schools thrived among the educated elites in Arabic culture. Yet at a later historical stage, during the twelfth century, we find the most serious students of this kind of rationalism becoming critical of it, seeking different ways to free themselves from its dogmatic grip. This critical challenging of dogmatic rationalism

34 See the discussion in the previous chapter.

35 Maimonides, Dalālat al-ḥä'irīn, II, 30 (245, ll. 6-21 = The Guide of the Perplexed, 349-50). 
posed by the leading thinkers of the era served as an important background to the integration of sceptical motifs in works by those thinkers. 
